DOI: $10.17951 /$ lrp. 2017.36.4.21

\author{
WALDEMAR FurmaneK
}

Uniwersytet Rzeszowski

\title{
W POSZUKIWANIU TOŻSAMOŚCI DYDAKTYKI INFORMATYKI
}

Streszczenie: Artykuł porusza tematykę miejsca, jakie zajmuje dydaktyka informatyki w naukach społecznych, a w szczególności w pedagogice. Stąd pojawia się pytanie: jakie są główne idee określające tożsamość merytoryczną i metodologiczną tej subdyscypliny pedagogiki?

Słowa kluczowe: dyscypliny pedagogiczne, dydaktyka, informatyka, społeczeństwo informacyjne

\section{WPROWADZENIE}

Wielu badaczy podejmujących problemy związane z wszechobecnością technologii informacyjnych nie identyfikuje swoich opracowań jako prac z zakresu badań problematyki dydaktyki informatyki ${ }^{1}$ (Furmanek, Piecuch 2004a, 2004b). Szczególną cechą tego rodzaju opracowań jest zbyt ubogie prezentowanie względu badań, jaki

${ }^{1}$ Warto w tym miejscu zauważyć, że w warunkach polskich wszystkie dydaktyki szczegółowe, często nazywane metodykami przedmiotowymi, nie są wpisywane na listy dyscyplin naukowych. Skutkuje to tym, że w zasadzie prac dotyczących tej problematyki badań nie uznaje się za dzieła wymagane w procedurach kwalifikacyjnych na stopnie naukowe. Podobna sytuacja dotyczy autorów podręczników metodycznych i podręczników szkolnych, których opracowanie nie jest uznawane za osiągnięcie naukowe.

Istotną różnicą między polskim i słowackim systemem szkolnictwa wyższego jest sklasyfikowanie dydaktyk szczegółowych jako dyscyplin naukowych należących do obszaru nauk o edukacji w dziedzinie nauk pedagogicznych. Dydaktyki szczegółowe oznaczone są symbolem cyfrowym 1.1.10, a praktycznie odnoszą się do wszystkich dydaktyk przedmiotowych, np. dydaktyki: biologii, matematyki, techniki, informatyki itp. Z zakresu dydaktyk szczegółowych możliwe jest uzyskiwanie stopni i tytułów naukowych począwszy od stopnia doktora a skończywszy na tytule profesora. Dydaktyki szczegółowe można studiować w ramach studiów III stopnia, tj. na studiach doktoranckich (por. Sústava študijných odborov SR, opublikowano: https://www.minedu. sk/sustava-studijnych-odborov-sr/). 
autor preferuje w tym konkretnym opracowaniu. To przede wszystkim wskaźnik słabej ekspansji naukowej dydaktyki informatyki jako subdyscypliny pedagogicznej. W obecnej sytuacji zauważamy, iż niektóre z opracowań mają charakter badań socjologicznych, inne zaś należy zaliczyć do pedagogiki czy psychologii bądź etyki (niestety niewiele jest takich opracowań).

Przykładowo do opracowań o charakterze socjologicznym należą te, które koncentrują się wokół kategorii społeczeństwo cyfrowe (społeczeństwo informacyjne). Do takich należą bez wątpienia problemy wpływu technologii informacyjnych na jakość życia ludzi. Jednak i ten problem ma wymiar pedagogiczny (por. Furmanek 2016). Bowiem jakość życia należy do kategorii teleologii wychowania. Często podejmowana jest problematyka analfabetyzmu cyfrowego. I podobnie jak wyżej może ona być ukierunkowana na problematykę społeczną charakterystyczną dla badań socjologicznych (np. stratyfikacja cyfrowa, zero-jedynkowa), ale może być postrzegana przez pedagoga jako odpowiedź na wyzwanie rozwijającego się społeczeństwa informacyjnego. Co powinni czynić pedagodzy, aby procesy rozwoju człowieka uwzględniały konieczność przygotowania każdego do obrony i budowy własnej tożsamości w dynamicznie rozwijającym się społeczeństwie informacyjnym? Jak zabezpieczyć człowieka przed marginalizacją społeczną, kulturową, cywilizacyjną? Powyższe przykłady pytań mieszczą się w siatce problematyki dydaktyki informatyki.

\section{POTRZEBA ROZWOJU DYDAKTYKI INFORMATYKI}

Wobec rosnącego w niebywałym tempie znaczenia technologii informacyjnych i informatyki dla jakości życia człowieka banalne jest stwierdzenie, że istnieje potrzeba rozwijania dydaktyki informatyki jako subdyscypliny pedagogicznej. Jej status ontologiczny i metodologiczny ciągle jeszcze nie jest wykrystalizowany. Jedno jest pewne: dydaktyka informatyki ma szansę rozwoju pod warunkiem pełnej integracji i w koneksji z osiągnięciami współczesnej pedagogiki, która powinna w większym stopniu odpowiadać na wyzwania współczesności.

Badania naukowe dotyczące szeroko rozumianej informatyki (tej uniwersyteckiej i tej politechnicznej) rozwijają się w szybkim tempie. Praktyczne wykorzystywanie tych osiągnięć w skali globalnej nie ma analogii w całej historii cywilizacji. Wyzwania, jakie wynikają z takiego stanu, dla pedagogiki współczesnej są wielorakie. Niestety pedagogika zaniedbała wiele z nich. Wśród zagubionych obszarów wymienić należy wyzwania, jakie przed pedagogiką stawia rozwijająca się cywilizacja informacyjna, a w tym także problemy społeczeństwa informacyjnego (Piecuch, Furmanek 2011). Trudno jest uznać za wystarczające rozwiązanie 
polegające na wprowadzaniu elementów informatyki czy technologii informacyjnych jako przedmiotów nauczania do planów nauczania szkół ogólnokształcących. Jednak treści informatyczne uwzględniono w kanonie wykształcenia ogólnego. To wymaga wypracowania i wdrożenia rozwiązań metodycznych i niezbędnej do ich wdrażania kompleksowej obudowy dydaktycznej.

W sytuacji aktualnie obserwowanej należy apelować do osób, które podejmują badania związane z problematyką dydaktyki informatyki, aby uświadomiły sobie przede wszystkim to, jak obecnie rozumie się i jak się interpretuje misję pedagogiki. W tym zaś to, jak interpretuje się pojęcie człowiek, i jak jego treść modeluje się w pedagogice. Wszak człowiek znajduje się w centrum zainteresowania wszystkich dyscyplin pedagogiki (por. Kozielecki 1998, 1988).

\section{MISJA PEDAGOGIKI JAKO SYSTEMU NAUK O EDUKACJI}

Misją pedagogiki jest wielostronne wspomaganie każdej osoby w procesach jej rozwoju, które ukierunkowane są na dobro człowieka. Owo wspomaganie ma miejsce w całożyciowych procesach dochodzenia do pełni człowieczeństwa. Tak ujęte sformułowanie wymaga szerszej interpretacji i odpowiedzi na podstawowe pytania (Bogdan Suchodolski określał je jako pierwsze).

Co oznacza pojęcie wspomagać? Sens tego terminu przybliżają jego synonimy: wspierać, podpierać, popierać, pomagać, dopomagać, firmować, dofinansowywać, sponsorować, dokładać się, dawać wsparcie, nieść/okazywać komuś pomoc, być/stać za kimś, stać przy czyimś boku, stać u czyjegoś boku, być/stać po czyjejś stronie, służyć komuś wsparciem, np. ramieniem, udzielać komuś pomocy, przychodzić komuś z pomocą.

Jaki jest sens pojęcia rozwój człowieka? Co oznacza wspomagać ten rozwój przez działalność pedagogiczną? Co oznacza wspomagać rozwój osoby w procesach wprowadzania człowieka w świat wartości? Jakie procesy występują na drodze dochodzenia człowieka do pełni jego dojrzałości aksjologicznej? Jakie zadania wynikają z każdego procesu wspomagania człowieka w jego dochodzeniu do pełni człowieczeństwa?

Wspomaganie jest świadomym działaniem, ukierunkowanym na wielorako rozumiane dobro człowieka. Wspomagać w stawaniu się człowiekiem to wspomagać w procesach wprowadzania wartości i życiu człowieka w przestrzeni aksjologicznej.

W strukturze działań wspomagających procesy rozwojowe człowieka wyróżnić można działania:

- kreatywne (gdy pedagog zamierza np. wywoływać, ukształtować),

- optymalizujące (gdy pedagog zamierza np. wzmóc, zwiększyć), 
- minimalizujące (gdy pedagog zamierza np. osłabić, ograniczyć),

- korekcyjne (gdy pedagog zamierza np. przekształcić, zmienić).

Celem działalności pedagogicznej jest wielostronne wspomaganie człowieka na jego drodze stawania się człowiekiem. Dodajmy - stawania się osobą, która radość życia będzie czerpać z godnego wykorzystywania osiągnięć cywilizacyjnych. Jednocześnie oznacza to zabezpieczenie tej osoby przed marginalizacją czy wykluczeniem społecznym, cywilizacyjnym i kulturowym (por. Piecuch, Furmanek 2013).

Wyjaśnić trzeba także, co oznacza stawanie się osobą. Przedmiotem badań nauk pedagogicznych jest człowiek jako osoba $\mathrm{z}$ całym systemem swoich potrzeb rozwojowych, jakie ujawniają się życiu, od poczęcia aż do naturalnej śmierci.

Osoba? Kim jest? Co znaczy dojrzałość osoby? Można to pojęcie analizować w ujęciu: biologicznym, psychologicznym, prawnym, pedagogicznym.

Zauważyć należy, iż dyskusję nad omawianymi problemami prowadzą różne nurty i kierunki polskiej pedagogiki, w tym także personalizmu. Na gruncie polskim antropologię personalizmu rozwijają w ostatnich czasach: Wincenty Granat, Stefan Świeżawski, Mieczysław A. Krąpiec, Mieczysław Gogacz, Henryk Gulbinowicz, Józef Życiński oraz Karol Wojtyła - papież Jan Paweł II.

\section{CZŁOWIEK JEST OSOBĄ}

Personalistyczna koncepcja człowieka w centrum stawia dobro i rozwój człowieka. Jest to koncepcja perfekcjonistyczna, przyjmująca, że człowiek dąży (i dążyć powinien) do realizacji rozpoznanych i zaakceptowanych najważniejszych wymiarów swojego człowieczeństwa. W tym kontekście należy stwierdzić, że wartości kształtują i doskonalą człowieka, odpowiadają jego podstawowym duchowym wymiarom (rozum, wola, wyczucie piękna). To wzorce doskonałości określonych przedmiotów, które odtworzone w tworach przyrody, dziełach ludzi lub wyobrażeniach człowieka wyrażają im właściwą wartościowość, dzięki czemu przedstawiają się człowiekowi jako lepsze od innych, są cenione i wyzwalają w ludziach swoiste duchowe przeżycia i dążenia (Ślipko 1974).

Integralny opis osoby umożliwia rozpatrywanie jej w aspekcie etycznym i aksjologicznym. Dobrze wyraża to stwierdzenie: ,integralna osoba ludzka jest to jednostkowy substancjalny i całkowity podmiot cielesno-duchowy zdolny działać w sposób rozumny, dobrowolny i społeczny (w celu harmonijnego ubogacania siebie i ludzkości w zakresie całego bytu)" (por. Granat 1976).

Osoba to podmiot cielesno-duchowy. W tym sformułowaniu zamknięte zostają wszystkie życiowe warstwy w modelu człowieka, wraz z jego podświadomością i nadświadomością. 
Osoba to podmiot jednostkowy. Nie jest nim zatem jakiś abstrakcyjny twór czy formalna idea. Dzięki tej właściwości osoba, osadzona w czasie i przestrzeni, sięga dalej w tym sensie, że im głębsza osobowość, tym wyższa indywidualność i jednostkowość człowieka.

Osoba to podmiot substancjalny. Pojęcie substancji, odnoszące się do osoby już od Boecjusza, wyraża zwartość bytu człowieka mimo przepływającego przez ludzkie „ja” strumienia świadomości, mimo jej dynamiki i ciągłego stawania się. Być podmiotem substancjalnym to znaczy być świadomym swej podmiotowości, być w sobie i przez siebie, ale już nie dla siebie (Furmanek - w druku).

Osoba działa w sposób rozumny, wolny i społeczny. Jest to - jak pisze Wincenty Granat w Personalizmie chrześcijańskim - naturalna tendencja osoby. Dzięki rozumności (wnioskowanie, tworzenie pojęć, sądzenie, intuicja) człowiek wyodrębnia się ze świata przyrody. Istotnym czynnikiem w tym procesie jest wolność, która oznacza tu brak jakiegokolwiek przymusu w zakresie działania i nie-działania; wiąże się ona z odrębnością, niepowtarzalnością, rozwojem i samoprzetwarzaniem (Granat 1961, s. 210).

Osoba działa w celu ustawicznego bogacenia siebie w zakresie całego bytu. Sformułowanie to pokazuje prawdę, że człowiek jest bytem nie tylko statycznym, ale stanowi też rzeczywistość płynną, dynamiczną. Realizuje siebie w działaniu, rozwija wszystkie bytowe warstwy, rozszerza swój horyzont przez tworzenie nowych wartości (Wojtyła 1985).

Do już wymienionych atrybutów człowieka jako osoby dodajmy następujące:

1) afirmacja każdego człowieka jako wartości podstawowej i naczelnej - jestem osobą, tzn. mam nieocenioną wartość;

2) prymat życia duchowego w człowieku w stosunku do innych dziedzin życia - jestem osobą, tzn. uznaję w sobie prymat ducha;

3) człowiek nie może być zredukowany (do ciała, zmysłów, fizjologii, producenta, robota), urzeczowiony (używany jako przedmiot) i traktowany instrumentalnie (jako narzędzie i środek) - jestem osobą, tzn. nie mogę być urzeczowiony;

4) osoba jest podmiotem tkwiących w naturze ludzkiej niezbywalnych praw; nie są one darem od społeczności czy władzy, ale tkwią w naturze ludzkiej - rozumnej, wolnej, zdolnej do odpowiedzialności, samoświadomości i samokierowania - jestem osobą, tzn. mam niezbywalne prawa;

5) afirmacja osoby i jej praw oznacza również świadomość powinności wobec innych, w odniesieniu do zasad sprawiedliwości - jestem osobą, tzn. mam zobowiązania i powinności;

6) moja godność wymaga stwierdzenia, iż jestem osobą, oznacza, że odrzucam totalitaryzm i liberalizm (por. Furmanek 2017). 
Uznajemy w tej koncepcji człowieka za szczególnie wyróżniony w naturze byt, którego cechami są: doświadczanie siebie jako osoby, duchowość, indywidualność, niepowtarzalność, jednorazowość ${ }^{2}$. Opracowanie strategii wspomagania rozwoju tych konstytutywnych atrybutów osoby powinno być strategicznym zadaniem dydaktyki informatyki ${ }^{3}$.

\section{POSTĘPOWANIA KATEGORIĄ DYDAKTYKI}

Swoistość człowieka ukazują jego postępowania. Zauważmy, że to pojęcie wiążemy z nadaniem czynom osobowego znaczenia (usensowienie) i odpowiadającym temu intencjonalnym splotom czynów człowieka w określonej sytuacji. Postępowania człowieka są szczególnie ważną kategorią opisu osoby, ukazują jej samoświadomościowy obraz. W ich kontekście jawi się nam to, iż w postępowaniach i przez nie człowiek jako osoba ujawnia swoiste dla siebie atrybuty ukazuje swoje niepowtarzalne - a więc występujące jednorazowo w całym okresie istnienia - określone wymiary człowieczeństwa (autonomiczność). Przez powtarzane w różnych sytuacjach postępowania człowiek sam staje się poniekąd coraz to innym człowiekiem (kognitywizm); buduje siebie, rozwija swoje człowieczeństwo, ujawniając jego właściwości w podejmowanych działaniach (transakcyjność).

Człowiek skazany jest na ciągły rozwój, który polega na systematycznym dążeniu do przekraczania zadanych granic rozwojowych (transgresja) i już zrealizowanych oczekiwań. Mówiąc krótko: człowiek jest bytem transgresyjnym. Intencjonalność, która tkwi immanentnie w strukturze treści postępowań, pozwala na pełniejsze zrozumienie osoby, swoistych dla niej właściwości, a także dążeń i metod postępowania.

Dążenia osoby do wzmocnienia szans rozwoju własnego - rozumianego jako umocnienie wewnętrznej integralności - domagają się właściwej człowiekowi ekspresji produktywnej, twórczej, zindywidualizowanej, bo stanowiącej rezultat świadomych wyborów i decyzji człowieka. To wymaga ciągłego rozwiązywania pojawiających się w jego życiu problemów. Jakość tych rozwiązań zależy od umie-

${ }^{2} \mathrm{~W}$ literaturze spotykamy różne definicje pojęcia człowiek. Podajmy kilka z nich: ens emans - istota kochająca, ens socjale - istota społeczna, ens ludens - istota bawiąca się, ens symbolicus istota symboliczna, ens religiosum - istota religijna, homo sapiens - człowiek mądry, homo faber - człowiek twórca, rzemieślnik, homo oeconomicus - istota ekonomiczna, homo esteticus - człowiek miłośnik piękna, homo creator - człowiek twórca, homo laborens - człowiek pracujący, homo inteligens - człowiek inteligentny, homo elektronicus - człowiek współdziałający, homo informaticus - człowiek ery robotyki i informatyki.

${ }^{3}$ Szczegółową charakterystykę dydaktyki informatyki można przeczytać w opracowaniach: Furmanek 2004a, s. 104-117; Furmanek 2004b, s. 118-128. 
jętności samopoznania, ale także od umiejętności wartościowania oraz poziomu zawansowania pracy nad sobą.

\section{ISTOTA TECHNOLOGII INFORMACYJNYCH}

Nie jest zakończona dyskusja dotycząca terminologii podstawowej w dydaktyce informatyki (Łucki 2018). Pojęcia, takie jak technika, technologia oraz odpowiednio techniki informacyjne, technologie informacyjne, są rozumiane rozmaicie. Nie wnikając w istotę kontrowersji, przyjmijmy, że technologie są komponentem techniki. W rozumieniu L. G. Backmana (1777) (profesor Akademii Nauk w Getyndze) w publikacji Anleitung zur Technologie greckie techno oznaczało rzemiosło lub sztukę, a logos - słowo, od dawna odnoszące się do nauki. Treściowo obejmuje ono odpowiedź na trzy pytania: co? z czego? jak? (por. Furmanek 1988). Najogólniej technologie można ujmować w znaczeniu szerokim (sensu largo) albo w znaczeniu wąskim (sensu stricto).

Technologie informacyjne, infotechnologie (ang. information technology, IT) to całokształt zagadnień, metod, środków i działań związanych z przetwarzaniem informacji. Stanowią połączenie zastosowań informatyki i telekomunikacji, obejmują również sprzęt komputerowy oraz oprogramowanie, a także narzędzia i inne technologie związane ze zbieraniem, przetwarzaniem, przesyłaniem, przechowywaniem, zabezpieczaniem i prezentowaniem informacji. Dostarczają użytkownikowi narzędzi, za pomocą których może pozyskiwać informacje, selekcjonować je, analizować, przetwarzać, gromadzić, zarządzać i przekazywać innym ludziom, a także może je likwidować.

W znaczeniu wąskim technologia to metoda przygotowania i prowadzenia procesu wytworzenia lub przetwarzania jakiegoś dobra (także informacji). Technologia to także sposób wykonania, technika wykonania, dział techniki, nauka o wytwarzaniu (lub przetwarzaniu) surowców (także informacji) lub półwyrobów w gotowe wyroby (wytwory i utwory). Wówczas technologia oznacza konkretny proces. Mówimy np. technologia klejenia, technologia malowania, technologia przetwarzania informacji. Taką też sytuację mamy w przypadku technologii informacyjnych. Przykładowo zapis informacji może być wykonany w różny sposób i na różnych nośnikach danych. 


\section{PARADYGMATY DYDAKTYKI INFORMATYKI}

Katalog paradygmatów dydaktyki informatyki wskazuje na to, że dyscyplina ta powinna odnosić się do wielopradygmatyczności swoich rozwiązań. Konieczność stosowania metodologii badań systemowych można uznać za pierwszy paradygmat dydaktyki informatyki. Nie mniej istotny jest paradygmat przyjmujący i uznający za fundamentalny model człowieka rozumiejącego. Wyraźnie wiąże się to z personalistycznym i fenomenologicznym nastawieniem wobec problematyki badań dydaktyki informatyki. W zasadzie jego treść wymusza konieczność rozpoznawania problemów człowieka o charakterze życiowym (egzystencjalnym). Dotychczas obserwujemy zainteresowanie badaczy modelami poznawczymi człowieka (kognitywistycznym). Dydaktyka informatyki powinna ten paradygmat eksponować.

Wszystkie problemy egzystencjalne człowieka mają charakter etyczny. Taki też charakter przypisać należy postępowaniom człowieka korzystającego w rozmaitym zakresie z technologii informacyjnych. Postępowania te składają się na indywidualną formę życia człowieka, profilują jego los, modelują sens życia i aktywności, ujawniają jego zmagania w poczuciu odpowiedzialności za życie własne z problemami codzienności. To zaś prowadzi do osobowego rozwoju i stanowi centralne zagadnienie psychologii personalistyczno-egzystencjalnej (Gałdowa 1990; Straś-Romanowska 1997).

Prymat człowieka nad techniką, jako jeden z paradygmatów, należy rozumieć szerzej jako prymat człowieka nad technologiami, w tym technologiami informacyjnymi. Wnioski płynące $z$ analiz treści wymienionego paradygmatu wyznaczać powinny zakres problemów szczegółowych dydaktyki informatyki. Dobro wychowanka we wszystkich wymiarach dobra (godziwe, utylitarne, hedonistyczne, uciążliwe, wspólne) jako naczelny cel działań pedagogicznych powinno wartościować podejmowane działania i wyznaczać kręgi problemów rozważanych w badaniach naukowych.

\section{FUNDAMENTALNE PROBLEMY DYDAKTYKI INFORMATYKI}

Wszechobecność technologii informacyjnych wynika z ich wielorakich funkcji facylitacyjnych. Wpisują się one w charakterystykę nowoczesnej techniki, modelując zjawiska życia człowieka i całych społeczeństw. Facylitacyjne funkcje technologii informacyjnych łatwo można obserwować na przykładzie dynamiki rozwoju i powszechności technologii telefonii komórkowych. Jednocześnie przykład ten ukazuje wyzwania, przed jakimi stają nauki pedagogiczne.

Problemy te wiążą się z takimi działaniami pedagogicznymi, które prowadzą do opanowania kompetencji warunkujących korzystne zmiany jakości życia 
człowieka. I pomimo tego, że teleologiczna problematyka jakości życia budzi kontrowersje i obecnie jest także obiektem badań, to dydaktycy informatyki powinni w swoich działaniach ten aspekt problematyki uwzględniać.

Jak modelować problematykę dydaktyki informatyki? Odpowiedź na to pytanie wymaga szerszego, oddzielnego opracowania. Zauważmy bowiem, że informatyka i jej technologie przenikają wszystkie dziedziny życia człowieka w każdym wieku (od dzieci przedszkolnych do studentów, także studentów uniwersytetów trzeciego wieku, od ludzi rozpoczynających pracę do ludzi w wieku późnej starości). Wiążą się ze wszystkimi rodzajami działalności człowieka i jego wspólnot; obejmują zjawiska życia społecznego w jego wszelkich odmianach.

Skoro tak, to jak optymalizować problematykę dydaktyki informatyki, jak pogodzić kanon wykształcenia ogólnego ze swoistymi właściwościami uczenia się informatyki? Już poszukiwanie odpowiedzi na pytanie, co znaczy uczyć się informatyki, stanowi niemałą trudność.

Jeżeli powiemy, iż uczyć się oznacza wzbogacać repertuar postępowań w życiu i pracy, to przywołane wcześniej pojęcie postępowania człowieka urasta do naczelnych kategorii dydaktyki informatyki. Jednocześnie zauważamy, iż postępowania człowieka w rozpoznanej sytuacji mają nie tylko wymiar behawioralny, ale przede wszystkim wymiar aksjologiczny. To zaś prowadzi nas do problematyki wychowania rozumianego jako wspomaganie rozwoju człowieczeństwa.

W tym kontekście należy rozważać dwa podstawowe problemy badań dydaktyki informatyki:

1) na ile technologie informacyjne mogą przyczyniać się do poprawy efektywności procesów wychowania człowieka?

2) na ile mogą wspomagać całożyciowe procesy uczenia się człowieka? I chociaż są to pytania podstawowe, dalecy jesteśmy od możliwości udzielenia na nie satysfakcjonującej odpowiedzi.

Problemy te osadzone są w swojej istocie w takich działaniach pedagogicznych, które prowadzą do opanowania kompetencji warunkujących korzystne zmiany jakości życia człowieka. I mimo tego, że teleologiczna problematyka jakości życia budzi kontrowersje, to dydaktycy informatyki powinni w swoich wysiłkach ten aspekt problematyki uwzględniać.

\section{LITERATURA}

Backman G., 1777, Anleitung zur Technologie (Wprowadzenie do technologii). Berlin.

Furmanek W., 1998, Zrozumieć technikę. Rzeszów, Wydawnictwo Oświatowe Fosze. 
Furmanek W., 2004a, Dydaktyka informatyki jako subdyscyplina pedagogiki współczesnej. W: W. Furmanek, A. Piecuch (red.), Dydaktyka informatyki. Problemy teorii. Rzeszów, Wydawnictwo Uniwersytetu Rzeszowskiego, 104-117.

Furmanek W., 2004b, Modele współczesnej dydaktyki informatyki. W: W. Furmanek,

A. Piecuch (red.), Dydaktyka informatyki. Problemy teorii. Rzeszów, Wydawnictwo Uniwersytetu Rzeszowskiego, 118-128.

Furmanek W., 2016, Humanistyczna pedagogika pracy. Praca a jakość życia człowieka. Rzeszów, Wydawnictwo Uniwersytetu Rzeszowskiego.

Furmanek W., Człowiek jako obiekt badań pedagogiki. Rzeszów, Wydawnictwo Uniwersytetu Rzeszowskiego (w druku).

Furmanek W., Piecuch A., 2004a, Dydaktyka informatyki. Problemy metodyki. Rzeszów, Wydawnictwo Uniwersytetu Rzeszowskiego.

Furmanek W., Piecuch A., 2004b, Dydaktyka informatyki. Problemy teorii. Rzeszów, Wydawnictwo Uniwersytetu Rzeszowskiego.

Gałdowa A., 1990, Rozwój i kryteria dojrzałości osobowej. „Przegląd Psychologiczny”, nr XXXIII/1.

Granat W., 1961, Osoba ludzka. Próba definicji. Sandomierz, Wydawnictwo Diecezjalne. Granat W., 1985, U podstaw humanizmu chrześcijańskiego. Poznań, Wydawnictwo Święty Wojciech.

Kozielecki J., 1988, O człowieku wielowymiarowym. Warszawa, PWN.

Kozielecki J., 1998, Koncepcje psychologiczne człowieka. Warszawa, Wydawnictwo Żak. Łucki Z., Proszę... nie mówmy „technologia” na technikę!, opublikowano: www.uci. agh.edu.pl/bip/63/11_63.htm [dostęp: 12.05.2017]

Piecuch A., Furmanek W. (red.), 2011, „Dydaktyka Informatyki”, nr 6: Problemy i wyzwania społeczeństwa informacyjnego. Rzeszów, Wydawnictwo Uniwersytetu Rzeszowskiego.

Piecuch A., Furmanek W. (red.), 2013, „Dydaktyka Informatyki”, nr 8: Informatyka wspomagająca całożyciowe uczenie się. Rzeszów, Wydawnictwo Uniwersytetu Rzeszowskiego.

Straś-Romanowska M., 1997, Los człowieka jako problem psychologiczny. Podstawy teoretyczne. Wrocław-Warszawa, Ossolineum.

Sústava študijných odborov SR, opublikowano: https://www.minedu.sk/sustava-studijnych-odborov-sr/ [dostęp: 12.05.2017].

Ślipko T., 1974, Zarys etyki ogólnej. Kraków, Wydawnictwo WAM.

Technologia informacyjna, opublikowano: https://www.scribd.com/document/181800992/

Technologia-informacyjna-pdf [dostęp: 12.05.2017].

Technologia, opublikowano: sjp.pwn.pl/slowniki/technologia.html [dostęp: 12.05.2017]. Wojtyła K., 1985, Osoba i czyn. Kraków, Polskie Towarzystwo Teologiczne. 
IN SEARCHING FOR IDENTITY OF INFORMATION DATA

\begin{abstract}
The article discusses the subject matter of the place of IT didactics in social sciences, and in pedagogy in particular. Hence, the question arises: what are the main ideas defining the substantive and methodological identity of this subdiscipline of pedagogy?
\end{abstract}

Keywords: pedagogical disciplines, didactics, IT, information society 